\title{
A Qualitative Study among Self-Identified Perfectionists and Procrastinators in Academic Tasks
}

\author{
Aylin Saltürk* \\ Child Development, Afyon Kocatepe University, Afyonkarahisar, Turkey
} ORCID: 0000-0003-4143-8917

\section{Article history}

Received:

01.03.2021

Received in revised form: 18.08.2021

Accepted:

08.09.2021

Key words:

Educational psychology,

Perfectionism,

Procrastination,

Academic tasks,

Student views
One of the elements constituting the globally growing interest in perfectionism and procrastination is today's education systems. In this study, which employed phenomenological model as one of the qualitative research methods, it was aimed to identify the motives for the perfectionism and procrastination of Science High School students within the framework of their own experiences and to determine what they need to overcome them. The data obtained through semi-structured interviews with 21 students selected by purposive sampling method were subjected to content analysis. In the analysis, a multidimensional perspective was adopted without considering a particular theoretical perspective on perfectionism and procrastination. As a result of the data analysis, it was seen that in addition to the standards the students determined for themselves, others' expectations were also among the motives of the students for perfectionism in academic tasks. Students need to overcome their fears of failure, get rid of academic procrastination and social support mechanisms with a view to coping with this situation. In addition, students procrastinate academic tasks due to the nature of the task, motivational problems, inadequacies in self-regulation skills, and fear of failure or fear of fail to be perfect. In order to cope with procrastination behaviors, they need to learn a number of both behavioral and cognitive regulations and increase their motivations.

\section{Introduction}

Perfectionism is a complex construct pertaining to individuals with characteristics such as setting unrealistic high standards and excessive concern for mistakes (JanssonFröjmark \& Linton, 2007). Adopting a multidimensional approach, Frost, Marten, Lahart and Rosenblate (1990) stated that perfectionism had six subdimensions, namely personal standards, family expectations, parental criticism, excessive concern about making mistakes, doubting one's behaviours, and order. Although it is associated with positive characteristics related to development and performance in daily use in clinical and personality psychology, perfectionism is often associated with low self-confidence (Ashby \& Rice, 2002), procrastination (Frost et al., 1990), depression and anxiety (Hewitt, Caelian, Flett, Sherry, Collins \& Flynn, 2002). Such problematic aspects, constituting also the subdimensions of the

\footnotetext{
* Correspondency: asalturk@aku.edu.tr
} 
perfectionism, appear in different forms such as excessive concern about making mistakes, doubting one's behaviours, setting impossibly high standards or self-evaluation based on expectations (Slaney, Rice, Mobbley \& Trippi, 2001). These conceptualisations have been supported with empirical findings, and typologies consisting of the combination of these negative aspects of perfectionism have been named as 'maladaptive/self-evaluative perfectionism' (Stoeber \& Otto, 2006). Since the high standards set by these individuals do not suit them and are irrational, these people often experience failure. This situation reduces their tolerance to making mistakes and limits their flexibility. Since they consider their selfworth in parallel with their performance, they experience intense anxiety in the tasks assigned and they have an all-or-nothing mindset with black-and-white thinking (Slaney et al., 2001). They enjoy their work very little; they feel competent, thus making negative evaluations about themselves. On the other hand, the typology that bears positive characteristics such as the cases where individuals are aware of themselves, their competencies and perfectionism, they set more realistic and achievable standards for themselves, strive for success but also accept failure and can make inferences from it, focus on doing things right, are more flexible against mistakes (Slaney et al., 2001), is called as 'adaptivel striving perfectionism' (Stoeber \& Otto, 2006).

The concept of procrastination is defined in different ways in the literature (Steel, 2007). Examining these definitions, it is seen that each of them discusses the psychosocial, cognitive, and behavioural dimensions by presenting different interpretations for procrastination, which is a complex and inclusive construct. Reviewing the literature, it is seen that these theories define procrastination as lack or a deficiency of self-regulation skills (Tuckman, 1990), deliberately delaying tasks to avoid discomfort (Solomon \& Rothblum, 1984), a buffer protecting against acts that will urge to face painful emotions and unsolved problems (Burka \& Yuen, 1983), dysfunctionality in the ability to set priorities and perform tasks without conflict (Milgram, Sroloff \& Rosenbaum, 1988), a tendency learned by means of environment and previous experience (Jaradat, 2004), a construct arising from dysfunctional beliefs (Jaradat, 2004) failure in self-regulation, which causes an adverse effect on learning and success (Wolters \& Corkin 2012), a harmful, devastating defence strategy lowering performance quality, where individual sabotages himself/herself (Van Eerde, 2003). Another theory by Freud (1953) defined procrastination as a natural outcome of anxiety, used as an ego defence mechanism (as cited in Jaradat, 2004). Evaluating these conceptualisations, it is seen that procrastination is discussed often by focusing only on the maladaptive aspect of it. This negative reputation of procrastination stems from the empirical fact that it is associated with reduced performance, health, and well-being (Steel, Brothen, \& Wambach, 2001; Tice \& Baumeister, 1997).

\section{Perfectionism and Procrastination in Academic Tasks}

Perfectionism and procrastination are the constructs that are often studied in the educational psychology in terms of their relationship with performance and motivation. The studies show that approximately one-fifth of the high school students are considered under the category of maladaptive/self-evaluative perfectionism due to their high personal standards, tendency towards self-criticism and excessive concern about making mistakes (Boone, Soenenes, Braet \& Goosens, 2010; Rice \& Ashby, 2007). In this regard, when characteristics that correspond to perfectionism include setting high standards and being motivated by them, it is associated with academic achievement whereas when it includes increased self-criticism and unrealistic standards, it is ascribed to reduced motivation. As a matter of fact, studies show that perfectionists are mostly affected in their academic/professional lives (Stoeber 
\&Stoeber, 2009). Adaptive / striving perfectionists have better control over anxiety due to reasons such as responsibility, time management skills and motivation (Burnam, Komarraju, Hamel, \& Nadler, 2014). However, maladaptive / self-evaluative perfectionists tend to adopt an avoidance behaviour through procrastination in order to meet the standards they set because they are not able to complete the task perfectly on time (Shafran \& Mansell, 2001). When combined with procrastination, perfectionism creates unsatisfactory results such as fear of failure in many areas of life (Fairburn, Cooper, Shafran, 2003).

Perfectionists are not motivated by the need to succeed, but by the fear of failure (Pacht, 1984). As a result of setting extremely high standards (Flett, Blankstein, Hewitt, \& Koledin, 1992), they experience problems in setting goals and performance anxiety (Egan, Wade, \& Shafran, 2011). Within this context, perfectionism is a possible precursor of the tendency to procrastinate (Flett, Hewitt, Davis, \& Sherry, 2004). It is seen that being accepted as purposive delay; procrastination is an inevitable situation for students. It remains popular among students as a construct that is frequently seen at different educational levels (Harriot \& Ferrari, 1996). It is estimated that approximately $95 \%$ of young people and adolescents experience procrastination at some point in their lives (Ellis \& Knaus, 1977; Steel, 2007). Studies show that students prefer more desirable activities such as watching TV, sleeping, and spending time with family and friends (Pychyl, Lee, Thibodeau, \& Blunt, 2000) to academic tasks such as writing a term paper, preparing for the exam (Solomon \& Rothblum, 1984). Additionally, it has been identified that almost $70 \%$ of the students were found to experience academic procrastination (Schouwenburg, 1995). Although it is so common, it is observed (Solomon \& Rothblum, 1984) that $60 \%$ of the students see academic procrastination as a problem and want to reduce it because of its such repercussions as stress and low grades (Tice \& Baumeister, 1997).

While perfectionism, low self-esteem, and evaluation anxiety are the main reasons for procrastination (Ferrari, 1992; Onwuegbuzie, 1997; Onwuegbuzie, 2000; Saddler \& Sacks, 1993; Solomon \& Rothblum, 1984), the source of this purposive procrastination behaviour varies based on individual differences as well as demographic variables. Reasons such as test anxiety, difficulty in making decisions, rebellion against control, fear of the results of success, fear of failure, avoidance of duty (Schraw, Wadkins, \& Olafson, 2007; Van Eerde, 2003) are among the motives for procrastination. A widely accepted assumption about procrastination is that it is a defence strategy followed by individuals having a fragile self-confidence and whose self-esteem depends on success to protect themselves and their self-esteem (Burka \& Yuen, 1983). Referring to external factors plays a role in protecting one's social image and self-esteem (Ferrari, 1991). Within this context, though having negative results in terms of performance, its eliminating anxiety temporarily and maintaining self-confidence make the tendency to procrastinate sustainable (Steel, 2007).

A recent meta-analysis study by Curran and Hill (2017) found out that youth perfectionism has steadily increased in the last 3 decades. According to Howe and Strauss (1991), current era urges young people to strive to be the best in many subjects, especially in academia (as cited in Twenge, Campbell \& Freeman, 2012). Not being satisfied with their achievements, young people are afraid of being evaluated negatively, and perceive unrealistic standards of success from their environment, exhibit perfectionist tendencies and procrastinate assigned tasks, which can affect their academic achievements. 


\section{Aim of the Study}

It is seen in the current literature that the structures of both perfectionism and procrastination tendencies are often studied in line with quantitative paradigm through the employment of self-report scales. However, this approach may limit the deep understanding of the factors that can affect procrastination and perfectionism (Martin, Marhs, Williamsson, \& Debus, 2003; Stake, 2010). Therefore, in this exploratory research study, it was aimed to identify the reasons of the perfectionism and procrastination of science high school students within the framework of their own experiences and to determine what they need to overcome perfectionism and procrastination. In this context, as suggested by Stake (2010), the related structures were researched in-depth, based on the subjective experiences of the students, without limitation to the variables in any theoretical background. Within this context, answers to the following research questions were sought:

(1) What are the students' motives for perfectionism in academic tasks?

(2) What do students need to overcome perfectionism in academic tasks?

(3) What are the students' motives for procrastination in academic tasks?

(4) What do students need to overcome procrastination in academic tasks?

Perfectionism and procrastination are psychological constructs comprising a starting point, following developments and final outcomes. In this regard, it is believed that this research study will contribute to the literature by providing useful strategies to understand perfectionism and procrastination through analyzing the reasons therefor and to determine what is needed to overcome perfectionism and procrastination according to science high school students, who have a high profile in Turkish Education System.

\section{Method}

\section{Research Model}

Defined as "revealing perceptions and current situations, collected through such methods as observation, interview and document analysis, in a realistic and holistic manner", qualitative research method, has been employed in this study in line with the purposes of the study (Yıldırım \& Şimşek, 2011: 39). In qualitative research, the researcher is concerned with understanding how people make sense of and conceptualise their worlds and experiences (Merriam, 2009). In this study, phenomenological method, one of the qualitative research methods, was used to analyse the concepts affecting performance such as perfectionism and procrastination from the perspective of students and to reveal their perceptions on motives for exhibiting these behaviours and on what they need to overcome the latter. Phenomenological method is a suitable research model for the studies aiming to evaluate the perceptions, experiences, and views of the individuals profoundly (Büyüköztürk, Çakmak, Akgün, Karadeniz \& Demirel, 2018). The findings are based on the subjective experiences of the participants (Denzin \& Lincoln, 1998) and allow for understanding students based on their 'own expressions' (Patton, 1980: 22). This method provides the opportunity to conduct an indepth analysis through a holistic approach on the points that might be overlooked with the quantitative methodology, allowing for more comprehensive understanding of the relative constructs (Slaney, Chadha, Mobley \& Kennedy, 2000). In this model, where the results are provided in a descriptive narrative method with direct speech reporting, the information obtained are interpreted within the framework of themes and codes (Y1ldırım \& Şimşek, 2011). 


\section{Study Group}

Purposive sampling method has been employed to ensure the participation as this study aims at interviewing cases full of perfectionists and procrastinators in academic tasks. In the purposive sampling method, the researcher specifies the characteristics suitable for the purpose of the research and includes suitable people for them. It is known that a competitive environment can affect students' self-worth and achievement behaviours (Covington, 1998), and perfectionism is a characteristic frequently seen in students with high levels of success (Rice, Leever, Christopher, \& Porter, 2006; Rice, Ashby, \& Gilman, 2011). Similarly, there are findings in the literature that students attending very selective schools tend to procrastinate more (Ferrari, Keane, Wolfe, \& Beck, 1998). In the light of these findings in the literature, students studying at Science High Schools, ranking high in Turkish Education System in terms of academic achievement, were included in the study. Considering that the most important developmental tasks are in the field of education (Santrock, 2020), adolescence is the period in which expectations for getting high grades within the specified standards are felt most intensely. Since 12th grade students are in an intensive preparation process for the national university placement exam (HEIE) ${ }^{1}$ inside and outside the school, their inclusion in the research was not deemed appropriate by the school administrators and psychological counselors of the school where the research was conducted. Accordingly, in terms of their ability to express themselves and to feel the pressure to succeed, only 11th grade students were included in the study group.

Sampling strategy was followed as suggested by Slaney, and Ashby (1996) and Slaney et al. (2000). In forming the study group, no specific definition, model or measurement of perfectionism and procrastination was used. Qualitative studies (Gotwals \& SpencerCavaliere, 2014), in which the sampling is determined with the measurement tools that are available and frequently used in the literature, limit the research as they evaluate the data from the perspective of the relevant model. Instead, participants describing themselves as perfectionists in academic tasks and declaring that they tend to procrastinate in academic tasks were included in the study. The most important benefit of this strategy is to limit the constructs to the framework of a specified model, by which it precludes an analysis (Slaney \& Ashby, 1996). In this regard, 21 students studying in the $11^{\text {th }}$ grade of a Science High School which is in Afyonkarahisar, Turkey in the academic year of 2020-2021 constitute the study group of this research. According to the demographic information obtained during the research, 13 of the participants are female and 8 are male, their ages ranging between 16 and 17.

\section{Data Collection}

Since the interviewing is recommended as the main data collection tool (Büyüköztürk et al., 2018) within the scope of phenomenological method, a semi-structured interview form was used in this study to identify the views of the high school students. Expert opinions $(n=3)$ were obtained on the draft form including six questions, prepared in line with the purposes of this research based on the literature review. In line with the opinions, necessary revisions were made. Then, the interview form was shared on an online platform with a small group $(n=5)$ representing the relative sample and their opinions on the clarity of the expressions were received. In line with the feedback received, the interview form was given its final form

\footnotetext{
${ }^{1}$ HEIE is the abbreviation of Higher Education Institutions Examination (in Turkish, Yükseköğretim Kurumları Sinavı). To get a bachelor's degree in a Turkish higher education institution, high school students must take this exam which takes place once a year. This exam thus concerns millions of Turkish students each year.
} 
consisting of four questions (see Annex 1 for sample interview questions). The form was shared online with the participants through web video conferencing. After the aim of the research was explained, interviews were conducted online with students willing to participate in the study. Additional questions were asked when there were unclear questions during the interviews or when the participants were asked to express their opinions in detail. The interviews lasting 30 minutes on average were recorded digitally. Students were given codes with the initial of the word 'student' (such as S1, S2) to ensure anonymity, and interviews were noted down word for word.

\section{Data Analysis}

The data obtained from the research were analysed using the content analysis procedure (Schilling, 2006). Content analysis is a research technique for "making replicable and valid inferences from texts (or other meaningful matter) to the context of their use." (Krippendorff, 2004: 18). With the content analysis, a categorical system including categories reflecting the main elements of the texts is obtained. These categories can be determined either deductively (theoretically derived from the literature) or inductively (only from the data set). Inductive categories are recommended especially when the researcher aims to uncover new findings. In this study, the data were analysed with an inductive iterative process as suggested by Braun and Clarke (2006). During the analysis, expertise on the qualitative data analysis of two other people other than the researcher was made use of (Patton, 1999). Themes were introduced as an output of discussions on analysts' comments throughout the data analysis process (Richards \& Morse, 2013). Analysts independently coded the transcripts and later came together to discuss preliminary themes. In order to refine the preliminary themes and create the main themes, analysts held meetings again. During this process, final themes and codes were achieved with cyclical and continuous comparisons (Glaser \& Strauss, 1967) made following the stages of analysis, code development/refinement and theme development/refinement. After the themes emerged, a hierarchical structure was created between the codes and the figures that best represented the findings were designed. In these designed figures, the hierarchical representation of the themes and codes obtained as a result of data analysis and the frequency (f) of these codes are presented.

\section{Data Quality}

As the qualitative research studies are not based on statistical calculations due to their nature (Brink, 1991), they are often criticised for being subjective, lacking a systematic structure, and having deficiencies in the reporting of the findings. In this regard, the criteria to increase the quality of the data in the qualitative research (Guba, 1981; Lincoln \& Guba, 1986; Maxwell, 1992) are discussed in the literature. Examining these discussions, Eisner (1991) suggests that such concepts as credibility and transferability replace the concepts of validity /reliability in qualitative research studies (as cited in Creswell, 2013; Corbin \& Strauss, 2007).

In order to increase the quality of the data in this research, necessary sampling scale for phenomenological method was achieved (Creswell, 2013; Charmaz, 2011; Merriam \& Tisdell, 2016); accordingly, conclusiveness (internal validity) of the research was ensured. The purpose of the research was explained to the participants, their consent was obtained for participation, and their anonymity and confidentiality were guaranteed. Since the participants were under the age of 18 , permission of their legal guardians was also obtained, and the interviews were conducted at their school of education within the time periods determined by the school administration. As for the transferability (external validity) of the research study, 
the processes of data collection tool, data collection and analysis were reported in detail (Yıldırım \& Şimşek, 2011). Data analysis was carried out independently with two other experts in qualitative data analysis (Patton, 1999) than the researcher. The codes developed after achieving themes and codes were compared and the percentage of agreement (Miles \& Huberman, 1994) was calculated. Average reliability percentage of the themes was identified to be $92.5 \%$ in this study, and it was identified that this matching level was identified to be sufficient (Miles \& Huberman, 1994) for the reliability of the coding.

\section{Findings}

The findings have been presented under four different sub-headings in accordance with the research questions. The hierarchical representation of the themes and codes obtained by data analysis and the frequency $(f)$ of the aforementioned codes are explained with figures under each sub-heading, with the direct quotes of the most notable participant and the researcher's interpretations stated right afterwards.

\section{Motives for perfectionism in academic tasks}

Results of the data analysis shows that students have stated the existence of their own expectations of themselves and other's expectations as reasons why they strive for perfection in academic tasks. According to the findings, there are two themes and four codes. The hierarchical representation of these themes and codes and the codes' frequency $(f)$ are presented in Figure 1.

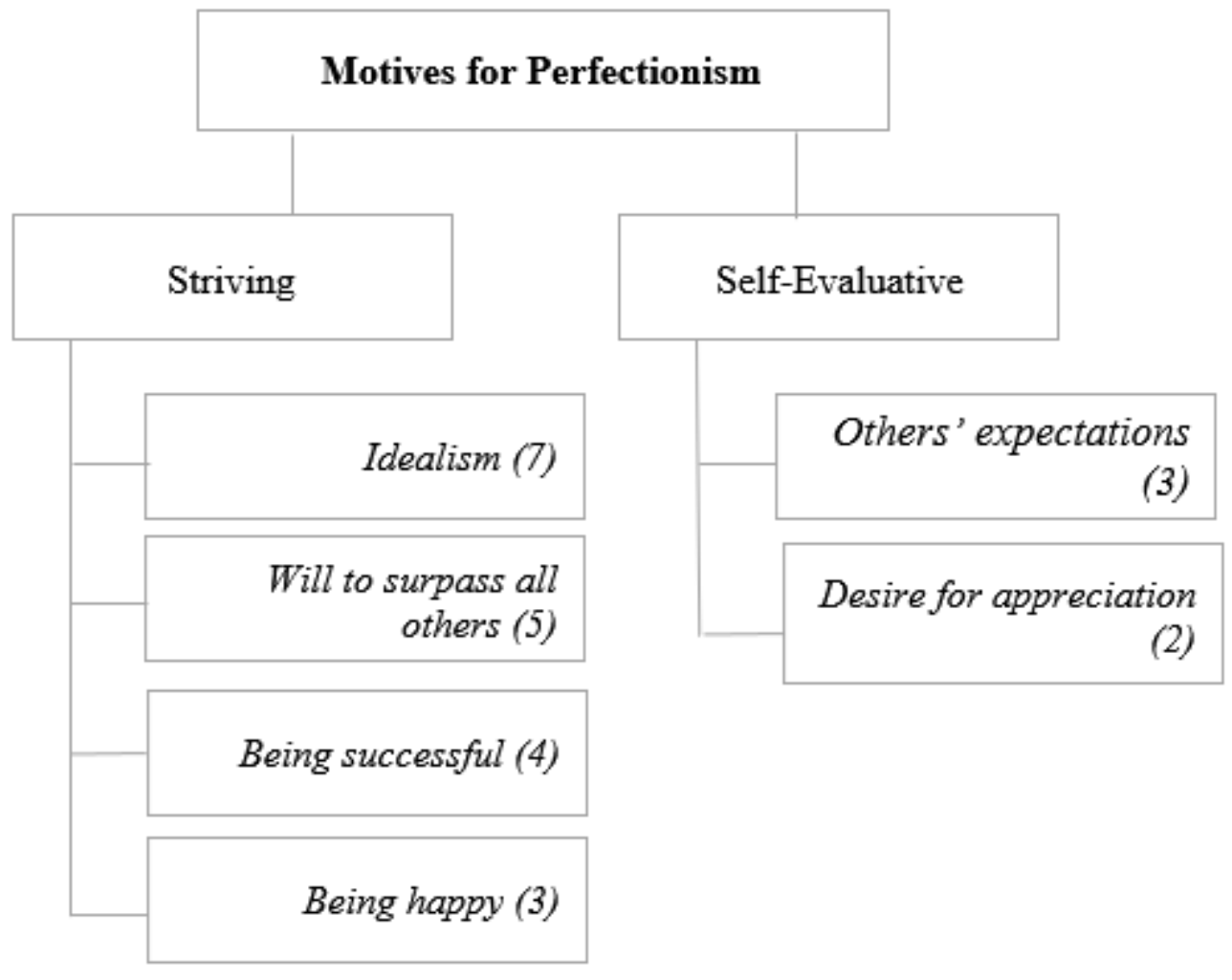

Figure 1. Participants' Motives for Perfectionism in Academic Tasks 
As shown in Figure 1, the most stated view under the "Striving" theme, which includes students' views on their own expectations from themselves and their standards as motives for perfectionism in academic tasks, is Idealism. For example, S3 explained that their motive for perfectionism in academic tasks was entirely related to their own ideals with the following statement: "I want that my knowledge on a subject I study to be complete or my daily work to be perfect. In general, I aim not to be superior or perfect over other people, but to be thela perfect version of myself.". It has also been remarked that, between the views under this theme, some students stated the Will to surpass all others as their motive for perfectionism in academic tasks. For example, S14, one of the participants, expressed their opinion by saying "I try to be perfect because I want perfection to be the biggest difference between me and others.".

In the meantime, the other codes under the "Striving" theme are Being successful (4) and Being happy (3). According to the findings, some students stated, as their motive for perfectionism in academic tasks, that they believe they could achieve success and be happy only if they were perfect. For example, S8 stated that they could be successful by trying to be perfect by saying "I try to be perfect because even if I can't always do my best, the time when I fall behind, I'll be at least still good if I aim to be perfect" while the student with the code S5 associated their motive for perfectionism with happiness: "If I leave something unfinished or don't do it perfectly, I get obsessed with it and feel unhappy".

Another point highlighted by participants is the expectations of students' family and friends and the students' desire for their appreciation, which has been coded under the "SelfEvaluative" theme. There are two codes under this theme, Others' expectations (3) and Desire for appreciation (2), as can be seen in Figure 1. One of the participants, S2, put emphasis on others' expectations by saying "I'm trying to be perfect because my family and the people around me are always putting pressure on me to do my best, and I guess with the fear arising from this pressure, I get obsessed excessively and try to do the best." while another participant, S6, put emphasis on the desire for others' appreciation with the following statement: "I try to be perfect as I think the more perfect, I am, the better the opinion of the people around me and their behaviors will be."

\section{Students' needs for overcoming perfectionism in academic tasks}

According to the data analysis, the findings on what students need to overcome perfectionism in academic tasks revealed three themes. The hierarchical representation of these themes and codes and the codes' frequency $(f)$ are shown in Figure 2. 


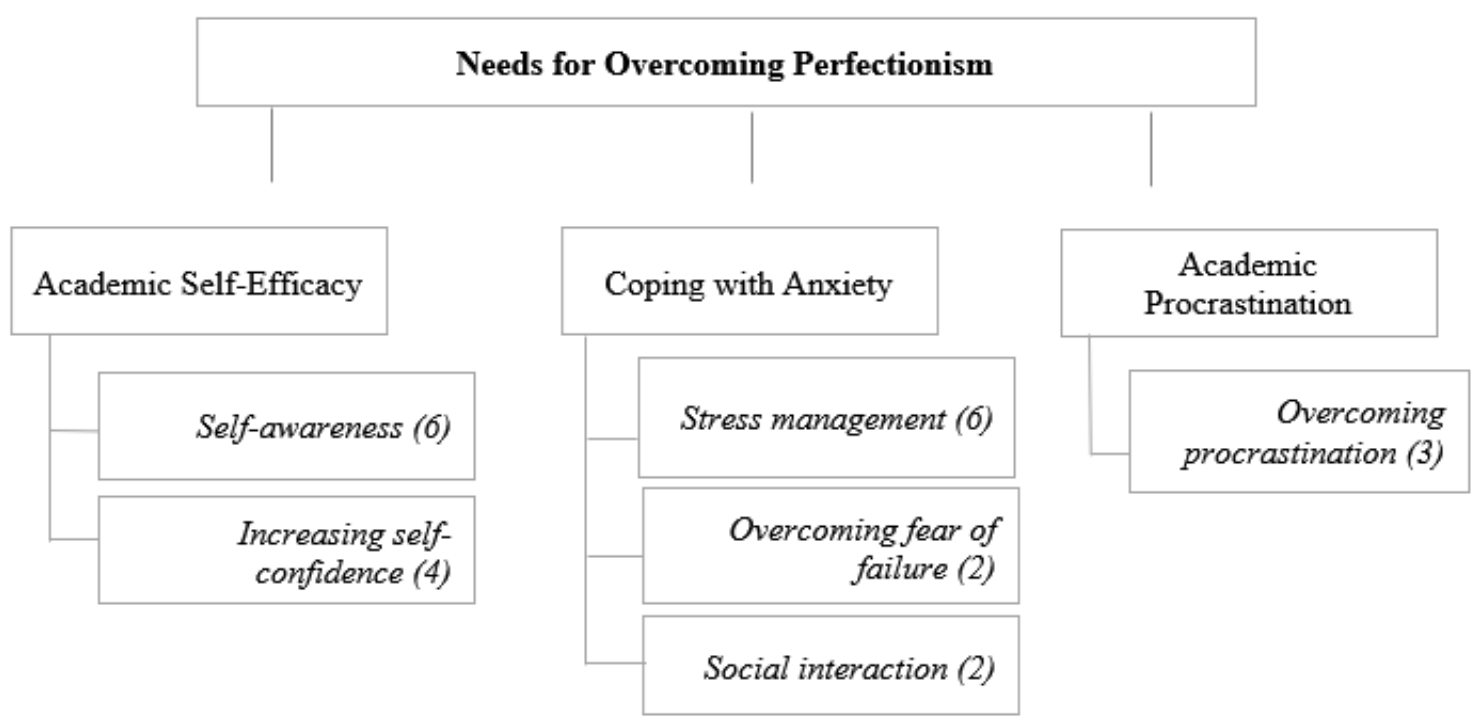

Figure 2. Participants' Need to Overcome Perfectionism in Academic Tasks

Findings showed that students need to develop their self-awareness to overcome perfectionism in academic tasks. As shown in Figure 2, the views under the "Academic SelfEfficacy" theme where these views have been examined, from most to least frequently stated are Self-awareness (6) and Increasing self-confidence (4). One of the participants, S2, stated their views as the following: "... That nothing is more important than me. To prove that this is my life and what I want matters above all, and I will live accordingly and to overcome my fears.". S2 also highlighted that they needed to increase their self-confidence by saying "I need to believe in myself, eradicate my prejudices. Additionally, I am a timid person, which is due to lack of self-confidence. I would like to get rid of it.".

Other things students stated were the existence of a stress they can't manage, that they experienced fear of failure and that they needed social support systems. These views were examined under the "Coping with Anxiety" theme. These codes are, from most to least stated, Stress management (6), Overcoming fear of failure (2) and Social interaction (2). One of the participants, S9, stated that they needed stress management by saying "I would like to get cleared of my stress and fears" while S16 stated the same thing by stating "I want to get rid of my useless anxieties". S19 stated the need to overcome the fear of failure by saying "To believe in myself for success and overcome the fear of failure" while S21 stated that they needed social support with the following words: "It would be nice to socialize with supportive people and feel their support".

According to the findings, the other theme underlined by students is "Academic Procrastination". The most frequently stated code between the views in this theme is Overcoming procrastination (3). According to the findings, students need to overcome academic procrastination in order to overcome perfectionism in academic tasks. One of the participants, S9, stated this desire by stating "...Getting rid of postponing would also be nice”. 


\section{Motives for procrastination in academic tasks}

According to the results of data analysis, students' motives for procrastination in academic tasks has been grouped under four themes: the nature of the task, their motivation, self-regulation skills and cognitive state. The hierarchical representation of these themes and codes and the codes' frequency $(f)$ are shown in Figure 3.

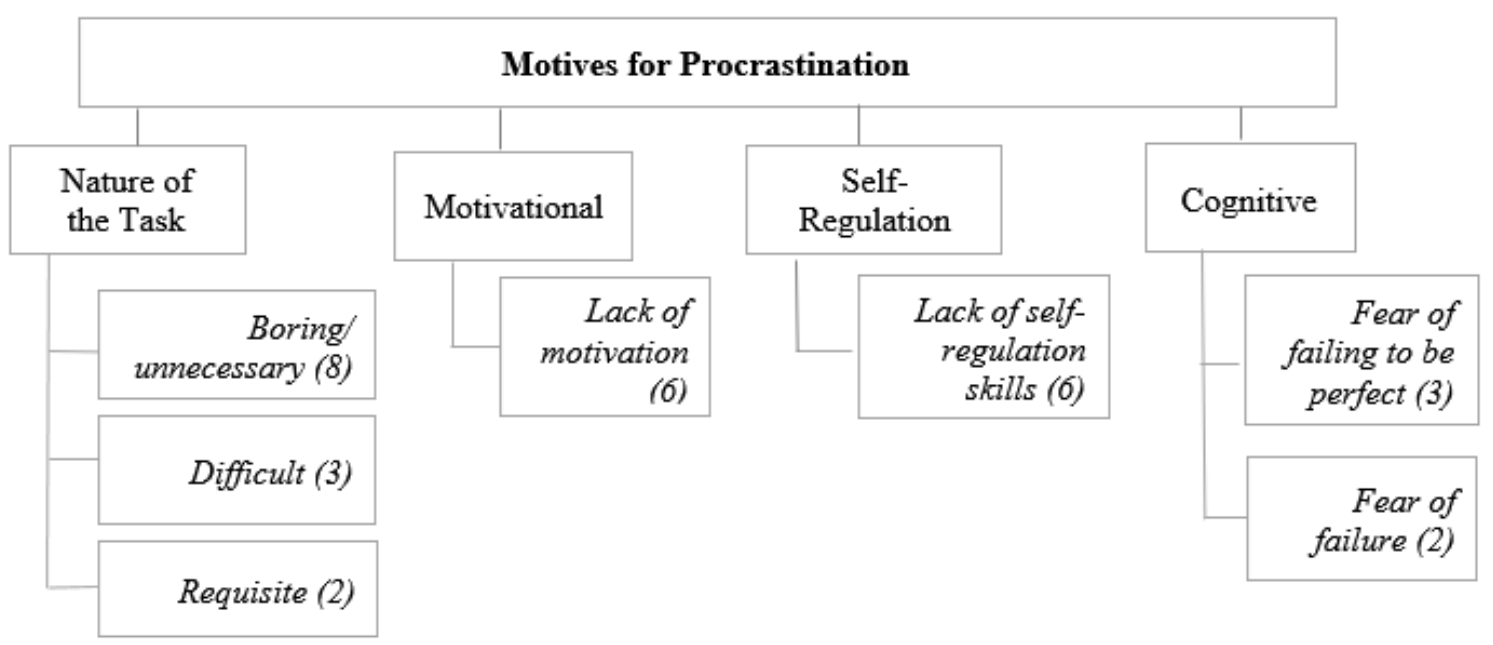

Figure 3. Participants' Motives for Procrastination in Academic Tasks

According to Figure 3, there are three codes when examining the views under the theme of "Nature of the Task". Accordingly, it is seen that students' views are related to them finding the academic tasks useless/boring and/or more difficult than they need to be, and the aforementioned tasks' being obligatory. For example, one of the participants, S9, stated their views on the given task being useless/boring by saying "I procrastinate a lot because if it is something really not interesting to me, I don't like doing it, especially when I think that it is not something that will not contribute to me...". Furthermore, according to data analysis, it has been discovered that the academic tasks being presented to students as obligatory without consulting the students or giving them a choice is a motive for procrastination. For example, one of the participants, S9, highlighted this situation by stating ".. and if it is a must that I do it, I procrastinate because the assignments are for grades, I mean, they are mandatory, but if they were up to us, then I would deal with them in my leisure time.". As a result of the analysis, the degree of difficulty of the given academic tasks was also discovered to be a motive for procrastination for students. One of the participants, S13, stated their views on the degree of difficulty by saying "...and sometimes I cannot do well in a lesson, which discourages me from studying, so I give up instead of pushing myself harder”.

Findings showed that students also experienced problems with motivation which prevented them from completing academic tasks on time. As seen in Figure 3, these views formed the "Motivational" theme. The views under the Lack of motivation (6) code under this theme showed that students can't overcome a lack of motivation. For example, one of the participants, S14, stated their views as the following: "I procrastinate because either I get too lazy to do it or I don't feel like doing it. I cannot cope with this reluctance of mine, so I procrastinate". 
However, the views constituting the theme of "Self-Regulation" in Figure 3 showed that the students expressed a feeling of inadequacy regarding self-regulation skills such as planning the study and managing time effectively in order to fulfill the educational activities on time. For example, S3 clearly states that, "I can delay starting because I am too busy with unnecessary things in my rest time, and I can't prevent it. As for finishing, if I don't have time to complete it, I postpone it."

The last theme under the motives for procrastination in academic tasks is the "Cognitive" theme. According to the findings show that students expressed a fear of not being able to perform educational activities perfectly and a fear of failure regarding said activities. S16 expressed his views about his fear of not being able to do the given task in the best way, "I procrastinate and even the idea of starting bothers me. Because I am afraid of failing to live up to what is expected from me...". Emphasizing that he is also afraid of failure, S16 stated his ideas as "Of course, I am afraid of failing because of it".

\section{Students' needs for overcoming procrastination in academic tasks}

Results of the data analysis showed that the findings regarding what students need to cope with procrastination of academic tasks reveal three themes. The hierarchical representation of these themes and codes and the frequency $(f)$ of these codes are presented in Figure 4.

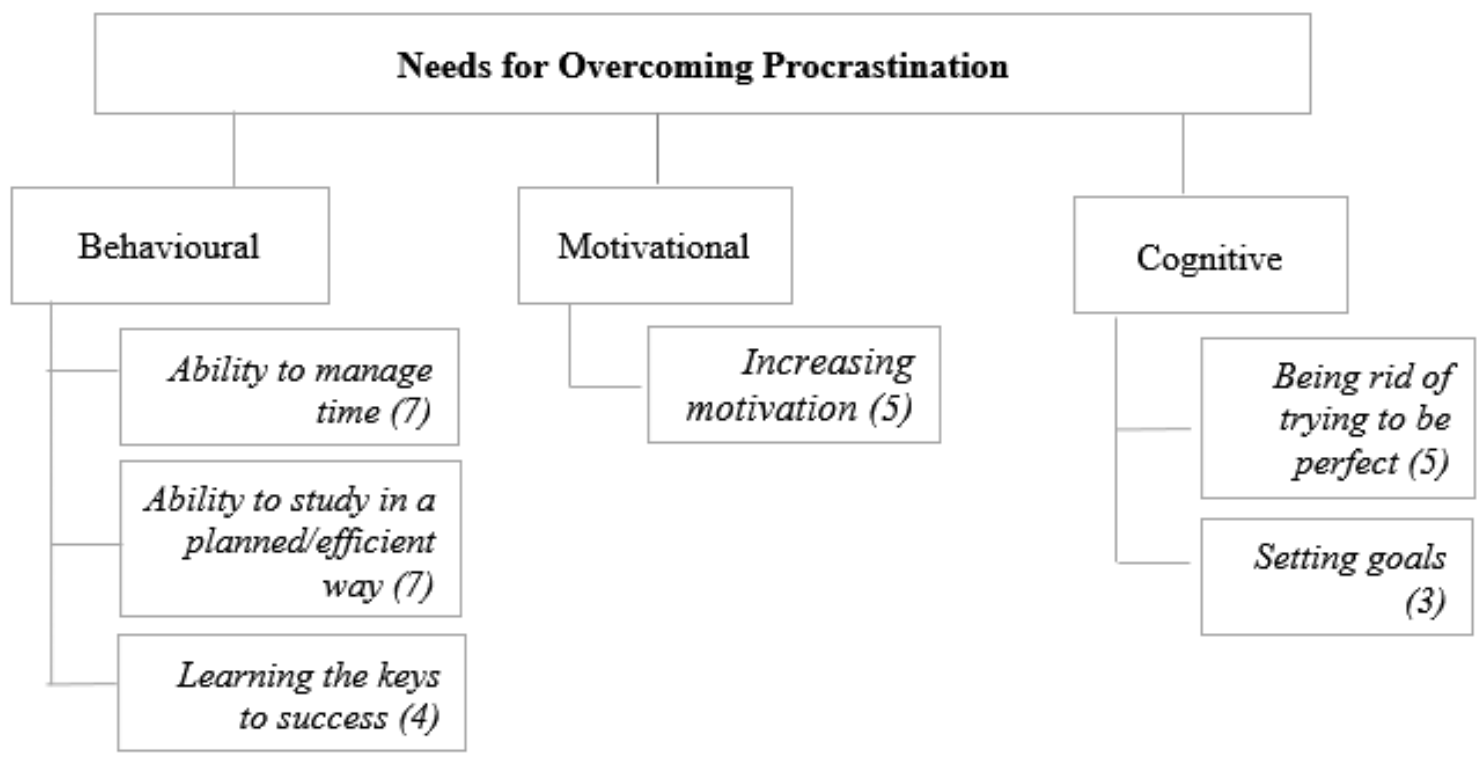

Figure 4. Participants' Needs for Overcoming Procrastination in Academic Tasks

Findings showed that students need to make some adjustments in their own behavior in order to cope with procrastination in academic tasks, and they need some guidance to do this. Views in this context were examined under the theme of "Behavioural" in Figure 4. When the codes under this theme were examined, it was seen that the students frequently stated that they want to gain time management and methodical/efficient study skills. For example, participant S10 expressed their views on their time management needs as "...to use time wisely and efficiently" and S13 as "to make use of the time well". However, S11 expressed a 
view about his desire to learn to study in a methodical/efficient way as "to gain the skill of studying in a planned manner". At the same time, the students underlined that they wanted to learn how to be successful. For example, S21 expressed his desire to learn to be successful as "to learn and implement what I need to be successful".

In the views under the "Motivational" theme in Figure 4, it was also seen that the students needed to increase their motivation in order to be more willing to do academic tasks. S20 expressed why they need to increase their motivation as "to learn, enjoying studying and motivating”.

The data analysis showed that students stated a need to change not only their behavior but also their cognitive state in order to cope with their academic procrastination behavior. Accordingly, it is seen that there are two codes in the views examined under the "Cognitive" theme in Figure 4. Students stated that they need to get rid of trying to be perfect and set a goal for themselves. S15, who stated her need to get rid of trying to be perfect, expressed their opinion as "to understand that being perfect is not the only thing defining me". On the other hand, S14 who addressed the need to set a goal expressed this issue in their words as "...I need to set and achieve goals".

\section{Discussion}

In this study, where students' expressions have been quoted with direct speech reporting in line with the qualitative paradigm, content analysis method has been used to identify the motives of the Science High School students for perfectionism and procrastination in academic tasks and what they need to overcome these two. In this study, a multidimensional perspective was adopted without considering a particular theoretical perspective on the relative psychological constructs. In this section, the findings related to perfectionism and procrastination have been summarized respectively and discussed within the framework of the research.

According to the results of this research study, the first theme established in association with students' motives for perfectionism in academic tasks is the theme of "Striving", which includes opinions on student expectations and standards (see Figure 1). Within the scope of the codes under this theme, students associated their motives for perfectionism in academic tasks with their ideals and will to be superior to others and stated that if they tried to achieve the perfection, they would become successful and happy. The existence of intrinsically high standards set for oneself in individuals is considered a harmonious aspect of perfectionism, as it is associated with individuals' high performance and, accordingly, increased academic success (Stoeber, 2012). As a matter of fact, in the interviews of Slaney et al. (2000) with the self-identified perfectionists, it was identified that the participants defined the perfectionism as a means for their successes in their careers. Within this context, it can be considered that having high academic achievement may make the students tend to become perfectionists (Flett, Hewitt, Oliver \& MacDonald, 2002). Since the students who participated in the research are those studying in Science High School due to their high success within Turkish Education System, their self-perception of high academic achievement and high self-efficacy creates the perception that perfection is attainable (Flett, Hewitt, Oliver, \& MacDonald, 2002) and increasing self-efficacy causes striving for high goals, leading individuals to overcome their past performances and strive to achieve further. (Bandura, 1989; Speirs Neumeister, 2004). 
According to the results of this research study, the second theme established in association with students' motives for perfectionism in academic tasks is the theme of "Self-Evaluative", where students clearly revealed the impact of others' expectations (see Figure 1). Within the scope of the codes under this theme, students' will to be appreciated is most emphasised. Taking this finding into account in the light of the theoretical knowledge in the literature, it is considered that students' being more aware of the expectations of success during the high school period (Eccles \& Midgley, 1989), when they are constantly evaluated in terms of performance in a competitive environment and compared with others (Eccles \& Midgley, 1989), plays a role in the development of perfectionism, and they may be striving to obtain this conditional approval from the environment. Indeed, the findings obtained through semistructured interviews in the literature demonstrate that students think that having high academic achievements in their past has increased the expectations of others from themselves (Speirs Neumeister, 2004) or that success has turned out to be a responsibility for them (Speirs Neumeister, Williams, \& Cross, 2009). Based on this, it can be evaluated that students, who attribute their self-worth to academic success, seek perfection to get approval from others (Hill, Hall, \& Appleton, 2011).

Another result of this study in relation to perfectionism in academic tasks is the determination of the fact that students needed a series of interrelated contextual and individual factors in order to overcome this situation. Evaluating the findings under the three themes established as a result of the data analysis in general (See Figure 2), it is understood that perfectionism has an important influence in students' academic progress and welfare, as was also stated by Jaradat (2013). One of the striking results in this context is that students stated that they needed to overcome their fears of failure and get rid of academic procrastination. As a matter of fact, there are findings in the literature in relation to the fact that individuals set unrealistically high and perfect goals and they procrastinated when they felt overwhelmed because they were not able to achieve these goals (Onwuegbuzie, 2000; Burka \& Yuen, 1983). Another result from this study was that students expressed the need to develop selfawareness and increase their self-confidence in order to believe that they could successfully complete academic tasks. In a sense, the perception of self-efficacy functions as a mediator between academic achievement and perfectionism (Nounopoulos et al., 2006). Indeed, there are findings demonstrating that individuals with perfectionist tendencies believe that they cannot achieve the standards they set even though they deliver great performance (Rice, Ashby \& Gilman, 2011), that they think that these high achievements increase the expectations of others from themselves even though they have had high academic achievements (Speirs Neumeister, 2004) and achievement has now become a task for them (Speirs Neumeister, Williams, \& Cross, 2009). For this reason, becoming aware of the incompatible aspects of perfectionism (Rice, Leever, Christopher \& Porter, 2006), setting realistic goals for themselves (Jaradat, 2013), lowering their standards (Egan, Piek, Dyck, Rees, \& Hagger, 2013) will be a good method for the students to overcome perfectionism. Another requirement highlighted by the students in this study is students' desire for social interaction with those understanding and supporting them. Perfectionism is developed as a result of social learning and conditional parenting (Bandura, 1977; Soenens, Luyckx, Vansteenkiste, Luyten, Duriez \& Goosens, 2008). As can also be seen in other studies pointing to the importance of the impacts of the contextual factors such as school environment, and the parents (Flett, Hewitt, Oliver \& MacDonald, 2002; Gilman \& Ashby, 2006), it is considered that students' having social support systems can play a supporting role in overcoming perfectionism. 
According to the results of this study, the first theme established in relation to the motives of the students for academic procrastination is "Nature of the Task" (see Figure 3). Students whose opinions were categorised into the codes under this theme stated that they procrastinated because they found the task boring / unnecessary or difficult. One of the striking findings under this theme was that the students stated that they postponed given tasks because the tasks were structured, planned, and delegated compulsorily by someone else, outside of their own initiative. These results are in line with the findings in the literature stating that academic procrastination occurs because students are afraid of the task given, find it difficult (Abramowski, 2018) and dislike the task (Steel, 2007). When the students find a task difficult, they attribute more importance to it and the task becomes scarier.

The second theme established in this study in relation to the motives for academic procrastination is "Motivational". This finding is in line with the research findings showing that procrastination is not only caused by the nature of the task but also by the failure to motivate themselves to perform a task within the specified period of time (Senecal, Koester \& Vallerand, 1995).

The third theme established in relation to the motives for academic procrastination is "SelfRegulation". As procrastinators lack self-control skills Steel, 2007; Senecal, Julien \& Guay, 2003), they have difficulty in sustaining their academic plans and achieving goals. They deliberately delay the task assigned to them as they believe that it would not require too much time and effort (Lay, 1990). Indeed, in this research, it has been identified that the students have expressed views related to lack of self-regulation skills such as time management, organising study habits, taking responsibility.

Academic procrastination, which is associated with failure in time management (Ferrari \& Diaz-Moreales, 2007) and lack of motivation (Senecal et al., 1995), is also an outcome of the perfectionism associated with fear of failure (Flett et al., 1992; Abramowski, 2018), as well. As a matter of fact, with the views examined under the theme "Cognitive", the last theme obtained through this research question, it has been established that some students attribute their reasons for procrastination to their fear of failure and not being perfect. In pursuit of perfection, procrastinators maintain their self-esteem and image. Since it is not possible for them to complete the task by fulfilling, the high standards they set, they display procrastination behaviour (Shafran \& Mansell, 2001). In this way, they have the opportunity to attribute failure to other factors and students continue to show a tendency to delay (Ferrari, 1992; Flett, Hewitt, Blankstein, \& Mosher, 1995; Steel, 2007).

Although academic procrastination is common among students (Schouwenburg, 1995; Steel, 2007), students acknowledge academic procrastination as a problem and want to reduce it due to its adverse effects on performance and the stress it creates (Tice \& Baumeister, 1997). Therefore, students were finally asked about their needs to overcome their procrastination behaviour in academic tasks. The findings were examined under three themes (see Figure 4). The most commonly reported views under these themes were the needs to gain the ability to manage time, to work in a planned/efficient manner and to learn ways to succeed, to increase their motivation, to get rid of their thoughts about being perfect, and to set themselves a goal. These requirements, clearly stated by the students, are in parallel with the literature. As a matter of fact, in order to cope with academic procrastination, some practices are applied as follows: Increasing the internal motivation of students in line with their needs (Burnam, Komarraju, Hamel \& Nadler, 2014), giving them a sense of responsibility (Steel, 2007), setting realistic goals by lowering the high standards they set (Egan, Piek, Dyck, Rees \&amp; Hagger, 2013), ensuring that they gain time management skills, raising their awareness about 
the social image and irrational beliefs about self-confidence (Patrzek, Sattler, vanVeen, Grunschel \& Fries, 2014).

\section{Conclusion}

One of the elements constituting the globally growing interest in perfectionism and procrastination is today's education systems. The perfectionism and procrastination tendencies of young people are increased by certain parameters of today's education system, such as the schools' needs to establish high standards, emphasise social comparisons and have a growing interest in rankings comparing the individual with the performance of others as well as the ambition of continuous self-development (Rice, Richardson, \& Ray, 2016).

Students are frequently exposed to competitive evaluation settings that have significant effects on personal standards of performance. Perfectionist tendencies arise from the individuals' setting extremely high standards based on previous performances due to the wishes and expectations of others (Onwuegbuzie, 2000). The desire for perfection is a human ideal that is closely linked to the need for self-realisation, but when it turns into a personality trait, it can have positive contributions as well as negative cognitive and emotional consequences for the individual, in this context, it can have a positive or negative effect on the individual's well-being. Examining the prevalence of perfectionist and procrastination tendencies among young people at the international level (Curran \& Hill, 2017; Sironic \& Revee, 2015; Ferrari \& Diaz-Morales, 2014; Steel \& Ferrari, 2013), the importance of guiding students towards reducing external performance pressure and setting realistic goals comes forth. As a matter of fact, this external performance pressure can create fear of failure. Students may have inaccurate cognitive assessment systems due to the effects of failure and the anxiety that their abilities or self-worth may be diminished as a result (Covington, 1992; Covington, 1998; Patrzek et al., 2014) and use procrastination as a defence strategy to protect their self-esteem by associating their self-esteem and self-worth with their achievements (Burka \& Yuen, 1983; Schubert \& Stewart, 2000). In this context, with procrastination, which can also be a defense strategy, the individual focuses on unproductive activities that lead to both low performance and negative emotions that affect their academic success (Schubert \& Stewart, 2000). As Hooda and Devi (2017) pointed out, while the implosive procrastinators procrastinate since they are unable to delay gratification, lack self-control and have low motivation, and have problems in perception and planning, the perfectionist procrastinators consciously avoid taking action because they are afraid of failure even though they are ready to work. In any case, procrastination has a devastating impact on the academic life of the students. In these cases, it is important for educators to define failure as a situation that can happen to everyone rather than a situation reflecting one's ability (Covington, 1992). Otherwise, the emergence of a risky youth in terms of both perfectionism and procrastination problems seems very likely.

\section{Limitations and Further Research}

The study group of this research consists of students having survived a competitive examination system and succeeded in being admitted to a school with high academic success. It was aimed to gain more in-depth information about the perfectionism and procrastination tendencies in academic tasks of the selected sample. Within this context, one of the limitations of this study is that it is not possible to generalise the findings to the whole young population due to the qualitative nature of the study and the small sample size of the study 
group. In future research, a study group consisting of students with different academic achievement levels can be formed.

Another limitation of this research is that the data were collected at a single time point (crosssectional). Longitudinal studies focusing on long-term consequences and changes in structure can be used to examine temporal changes in perfectionism and procrastination. In this way, the researcher can learn about the relevant structure from a broader perspective and understanding (Haynes, 2000). However, since a conceptual measure of the examined constructs was not used while forming the study group of the research, it is not clear whether the participants in the research could be considered perfectionist or procrastinators, to what extent they are so or what exact type they bear. Accordingly, the similarities and differences in the findings presented are likely to reflect variations depending on the frequency and type of perfectionism and procrastination tendencies of the participants. In future studies, the use of quantitative measurements may be considered in sample selection.

In this study, the motives of the Science High School students for perfectionism and procrastination in academic tasks and what they need to overcome these constructs have been examined. In future studies, students can be asked how they see the effect of perfectionism on their academic performance in order to examine the relevant constructs in the light of student experiences. Additionally, procrastinators can be asked about their strategies to overcome this situation and their families' reactions to success/failure. Furthermore, the findings obtained from this study demonstrate that students need support to cope with both psychological structures. In this regard, intervention-oriented practices (such as group counselling sessions, psychoeducation programmes) can be designed in future studies.

\section{Acknowledge}

Conflict of interest: Author(s) have no conflict of interest.

Ethical statements: Prior to carrying out the research, the authorization of Committee of Scientific Research and Publication Ethics for Social Sciences and Humanities in Afyon Kocatepe University was sought and granted (Decision 2021/47).

Informed consent: Informed consent was obtained from all individual participants involved in the study. 


\section{References}

Abramowski, A. (2018). Is procrastination all that "bad"? A qualitative study of academic procrastination and self-worth in postgraduate university students. Journal of Prevention \& Intervention in the Community, 46(2), 158-170. https://doi.org/10.1080/10852352.2016.1198168

Ashby, J. S., \& Rice, K. G. (2002). Perfectionism, dysfunctional attitudes, and self-esteem: A structural equations analysis. Journal of Counselling and Development, 80, 197-203. https://doi.org/10.1002/j.1556-6678.2002.tb00183.x

Bandura, A. (1977). Social learning theory. Oxford: Prentice-Hall

Bandura, A. (1989). Regulation of cognitive processes through perceived self-efficacy. Developmental Psychology, 25, 729-735. https://doi.org/10.1037/0012-1649.25.5.729

Braun, V., \& Clarke, V. (2006). Using thematic analysis in psychology. Qualitative Research in Psychology, 3:2, 77-101, DOI: 10.1191/1478088706qp063oa

Brink, P. J. (1991). Issues of reliability and validity. In J. M. Morse (Ed.), Qualitative nursing research: A contemporary dialogue (pp. 164-186). Newbury Park, CA: Sage. https://dx.doi.org/10.4135/9781483349015.n20

Burka, J.B. \& Yuen, L.M. (1983). Procrastination: why you do it, what to do about it. Reading, Mass.: Addison Wesley Pub. Co.

Burnam, A., Komarraju, M., Hamel, R., \& Nadler, D. R. (2014). Do adaptive perfectionism and self-determined motivation reduce academic procrastination? Learning and Individual Differences, 36, 165-172. https://doi.org/10.1016/j.lindif.2014.10.009

Büyüköztürk, Ş., Çakmak, E., Akgün, Ö. E., Karadeniz, Ş., \& Demirel, F. (2018). Scientific Research Methods. Ankara: Pegem Publ.

Boone, L., Soenens, B., Braet, C., \& Goossens, L. (2010). An empirical typology of perfectionism in early-to-mid adolescents and its relation with eating disorder symptoms. Behaviour Research and Therapy, 48(7), 686-691. https://doi.org/10.1016/j.brat.2010.03.022

Charmaz, K. (2011). Grounded Theory Methods in Social Justice Research. In N. K. Denzin \& Y. Lincoln (Eds), The Sage Handbook of Qualitative Research, $4^{\text {th }}$ Ed (pp. 359380). Thousand Oaks, CA: SAGE.

Creswell, J.W. (2013). Qualitative Inquiry and Research Design: Choosing Among Five Approaches. Thousand Oaks, SAGE Publications, Inc.

Curran, T. \& Hill, A. P. (2017). Perfectionism is increasing over time: a meta-analysis of birth cohort differences from 1989 to 2016. Psychological Bulletin, 145(4), 410-429. http://dx.doi.org/10.1037/bul0000138

Corbin, J., \& Strauss, A. (2007). Basics of qualitative research: Techniques and procedures for developing grounded theory (3rd ed,). Thousand Oaks, CA: Sage. https://dx.doi.org/10.4135/9781452230153

Covington, M. V. (1992). Making the grade: A self-worth perspective on motivation and school reform. Cambridge: Cambridge University Press. https://doi.org/10.1017/CBO9781139173582

Covington, M. V. (1998). The will to learn: A guide for motivating young people. Cambridge: Cambridge University Press.

Cox, B.J., Enns, M.W. \& Clara, I.P. (2002). The multidimensional structure of perfectionism in clinically distressed and college student samples. Psychological Assessment, 14(3), 365-373. https://doi.org/10.1037/1040-3590.14.3.365

Denzin, N. K., \& Lincoln, Y. S. (1998). Strategies of qualitative inquiry. Thousand Oaks, CA: 12 Sage. 
DiBartolo, P.M., Frost, R.O., Dixon, A. \& Almodovar, S. (2001). Can cognitive restructuring reduce the disruption associated with perfectionistic concern? Behaviour Therapy, 32, 167-184. https://doi.org/10.1016/S0005-7894(01)80051-4

Eccles, J. S., \& Midgley, C. M. (1989). Stage-environment fit: Developmentally appropriate classrooms for young adolescents. In R. E. Ames \& C. Ames (Eds.), Research on motivation in education (Vol. 3, pp. 139-186). San Diego, CA: Academic Press.

Egan, S. J., Piek, J. P., Dyck, M. J., Rees, C. S., \& Hagger, M. S. (2013). A clinical investigation of motivation to change standards and cognitions about failure in perfectionism. Behavioural and Cognitive Psychotherapy, 41(5), 565-578. https://doi.org/10.1017/S135246581200063X

Egan, S. J., Wade, T. D., \& Shafran, R. (2011). Perfectionism as a Transdiagnostic Process: A Clinical Review. Clinical Psychology Review, 31, 203-212. http://dx.doi.org/10.1016/j.cpr.2010.04.009

Ellis, A., \& Knaus, W. J. (1977). Overcoming procrastination. New York: Institute for Rational Living.

Ellis, A. \& Knaus, W. J. (2002) Overcoming procrastination (Rev. ed.). NY: New American Library

Enns, M.W. \& Cox, B.J. (2002). The nature and assessment of perfectionism: A critical analysis. In Flett, G.L., Hewitt, P.L. (Eds), Perfectionism: Theory, Research, and Treatment (33-62). American Psychological Association: Washington, DC, USA.

Flett, G.L., Hewitt, P.L., \& Martin, T.R. (1995). Dimensions of Perfectionism and Procrastination. In J.R. Ferrari, J.L. Johnson, \& W.G. McCown, (Eds.), Procrastination and task avoidance: Theory, research, and treatment. (113-136). New York: Plenum Press.

Flett, G. L., Hewitt, P. L., Davis, R. A., \& Sherry, S. B. (2004). Description and Counseling of the Perfectionistic Procrastinator. In H. C. Schouwenburg, C. H. Lay, T. A. Pychyl, \& J. R. Ferrari (Eds.), Counselling the procrastinator in academic settings (181-194). American Psychological Association. https://doi.org/10.1037/10808-013

Fairburn, C. G., Cooper, Z., \& Shafran, R. (2003). Cognitive behaviour therapy for eating disorders: a "transdiagnostic" theory and treatment. Behaviour Research and Therapy, 41(5), 509-528. https://doi.org/10.1016/s0005-7967(02)00088-8

Ferguson, K. L., \& Rodway, M. R. (1994). Cognitive behavioral treatment of perfectionism: Initial evaluation studies. Research on Social Work Practice, 4(3), 283308. https://doi.org/10.1177/104973159400400302

Ferrari, J. R. (1991). Self-handicapping by procrastinators: Protecting self-esteem, socialesteem, or both? Journal of Research in Personality, 25(3), 245261. https://doi.org/10.1016/0092-6566(91)90018-L

Ferrari, J. R. (1992). Procrastinators and perfect behaviour: An exploratory factor analysis of self-presentation, self-awareness, and self-handicapping components. Journal of Research in Personality, 26(1), 75-84. https://doi.org/10.1016/0092-6566(92)90060$\mathrm{H}$

Ferrari, J. R., Johnson, J. L., \& McCown, W. G. (1995). The Plenum series in social/clinical psychology. Procrastination and task avoidance: Theory, research, and treatment. Plenum Press. https://doi.org/10.1007/978-1-4899-0227-6

Ferrari, J. R., Keane, S. M., Wolfe, R. N., \& Beck, B. L. (1998). The antecedents and consequences of academic excuse-making: examining individual differences in procrastination. Research in Higher Education, 39(2), 199-215. https://link.springer.com/article/10.1023\%2FA\%3A1018768715586 
Ferrari, J. R., \& Diaz-Morales, J. F. (2007). Procrastination: Different time activation reflect different motives. Journal of Research in Personality, 41, 707-714. https://doi.org/10.1016/j.jrp.2006.06.006

Ferrari, J. R., \& Díaz-Morales, J. F. (2014). Procrastination and mental health coping: A brief report related to students. Individual Differences Research, 12(1), 8-11.

Flett, G.L.; Blankstein, K.R.; Hewitt, P.L. \& Koledin, S. (1992). Components of perfectionism and procrastination in college students. Social Behaviour and Personality: An international journal, 20(2), 85-94. https://doi.org/10.2224/sbp.1992.20.2.85

Flett, G. L., Hewitt, P. L., Blankstein, K. R., \& Mosher, S. W. (1995). Perfectionism, life events, and depressive symptoms: A test of a diathesis-stress model. Current Psychology: A Journal for Diverse Perspectives on Diverse Psychological Issues, 14(2), 112-137. https://doi.org/10.1007/BF02686885

Flett, G. L., Hewitt, P. L., Oliver, J. M., \& MacDonald, S. (2002). Perfectionism in children and their parents: A developmental analysis. In G. L. Flett \& P. L. Hewitt (Eds.), Perfectionism: Theory, research, and treatment (pp. 89-132). Washington, DC: American Psychological Association. https://doi.org/10.1037/10458-004

Frost, R. O., Marten, P., Lahart, C., \& Rosenblate, R. (1990). The dimensions of perfectionism. Cognitive Therapy and Research, 14(5), 449468. https://doi.org/10.1007/BF01172967

Gilman, R., \& Ashby, J. S. (2006). Perfectionism. In G. G. Bear \& K. M. Minke (Eds.), Children's needs III: Development, prevention, and intervention (pp. 303-312). Bethesda, MD: National Association of School Psychologists

Glaser, B. G., \& Strauss, A. L. (1967). The Discovery of Grounded Theory: Strategies for 13 Qualitative Research. Chicago, IL: Aldine Publishing Company http://www.sxf.uevora.pt/wp-content/uploads/2013/03/Glaser_1967.pdf

Guba, E. G. (1981). Criteria for assessing the trustworthiness of naturalistic inquiries. Educational Technology Research and Development, 29(2), 75-91. https://www.jstor.org/stable/30219811?seq=1\#metadata_info_tab_contents

Gotwals, J. K., \& Spencer-Cavaliere, N. (2014). Intercollegiate perfectionistic athletes' perspectives on achievement: Contributions to the understanding and assessment of perfectionism in sport. International Journal of Sport Psychology, 45, 271-297. https://doi.org/10.1080/10413200.2020.1740826

Harriott, J. \& Ferrari, J.R. (1996). Prevalence of procrastination among samples of adults. Psychological Reports 78, 611-616. https://doi.org/10.2466/pr0.1996.78.2.611

Haynes, N. (2000). Doing psychological research. Philadelphia: Open University Press

Hewitt, P. L., Caelian, C. F., Flett, G. L., Sherry, S. B., Collins, L., \& Flynn, C. A. (2002). Perfectionism in children: Associations with depression, anxiety, and anger. Personality and Individual Differences, 32(6), 10491061. https://doi.org/10.1016/S0191-8869(01)00109-X

Hill, A.P., Appleton, P.R. \& Hall, H.K. (2011). The relationship between multidimensional perfectionism and contingencies of self-worth. Personality and Individual Differences, 50 (2). 238 - 242 (5). https://doi.org/10.1016/j.paid.2010.09.036

Hooda, M. \& Devi, R. (2017). Procrastination: A Serious Problem Prevalent Among Adolescents. ZENITH International Journal of Multidisciplinary Research, 7 (9), 107113.

Jansson-Frojmark, M., \& Linton, S. J. (2007). Is perfectionism related to pre-existing and future insomnia? A prospective study. British Journal of Clinical Psychology, 46, 119-124. https://doi.org/10.1348/014466506X158824 
Jaradat, A.K.M. (2004). Test anxiety in Jordanian students: Measurement, correlates and treatment. Doctoral Dissertation, Philips: University of Marburg http://archiv.ub.unimarburg.de/diss/z2004/0124/pdf/dakmj.pdf

Jaradat, A.K.M. (2013). Multidimensional perfectionism in a sample of Jordanian high school students. Australian Journal of Guidance and Counselling, 23, 95-105. https://doi.org/10.1017/jgc.2012.20

Krippendorff, K. (2004). Content Analysis: An Introduction to Its Methodology (2nd ed.). Thousand Oaks, CA: Sage

Lay, C.H. (1990). Working to schedule on personal projects: An assessment of person-project characteristics and trait procrastination. Journal of Social Behaviour and Personality, 5, 91-103. https://psycnet.apa.org/record/1990-30967-001

Lincoln, Y. S., \& Guba, E. G. (1986). But is it rigorous? Trustworthiness and authenticity in naturalistic evaluation. New Directions for Evaluation, (30), 73-84. https://doi.org/10.1002/ev.1427

Lo, A., \& Abbott, M. (2013). The impact of manipulating expected standards of performance for adaptive, maladaptive, and non-perfectionists. Cognitive Therapy and Research, 37, 762-778. https://doi.org/10.1007/s10608-013-9528-1

Martin, A. J., Marsh, H. W., \& Debus, R. L. (2003). Self-handicapping and defensive pessimism: A model of self-protection from a longitudinal perspective. Contemporary Educational Psychology, 28, 1-36. https://doi.org/10.1016/s0361-476x(02)00008-5

Maxwell, J. (1992). Understanding and validity in qualitative research. Harvard Educational Review, 62(3), 279-301. https://doi.org/10.17763/haer.62.3.8323320856251826

Merriam, S. B. (2009). Qualitative research: A guide to design and implementation. San Francisco, CA: Jossey-Bass.

Merriam, S. B., \& Tisdell, E. J. (2016). Qualitative Research: A Guide to Design and Implementation (4th ed.). San Francisco, CA: Jossey-Bass.

Milgram, N. A., Sroloff, B., \& Rosenbaum, M. (1988). The procrastination of everyday life. Journal of Research in Personality, 22(2), 197212. https://doi.org/10.1016/0092-6566(88)90015-3

Milgram, N., Marshevsky, S., \& Sadeg, C. (1995). Correlates of academic procrastination: Discomfort, task aversiveness, and task capability. The Journal of Psychology, 129, 145-155. DOI: 10.1080/00223980.1995.9914954

Miles, M, B., \& Huberman, A. M. (1994). Qualitative data analysis: An expanded Sourcebook. (2nd ed). Thousand Oaks, CA: Sage.

Nounopoulos, A., Ashby, J. S., \& Gilman, R. (2006). Coping resources, perfectionism, and academic performance among adolescents. Psychology in the Schools, 43(5), 613622. https://doi.org/10.1002/pits.20167

Onwuegbuzie, A.J. (1997). Writing a research proposal: The role of library anxiety, statistics anxiety, and composition anxiety. Library \& Information Science Research, 19(1), 533. https://doi.org/10.1016/S0740-8188(97)90003-7

Onwuegbuzie, A. (2000). Academic procrastinators and perfectionistic tendencies among graduate students. Journal of Social Behaviour and Personality. 15(5), 103-109. https://psycnet.apa.org/record/2002-10572-008

Pacht, A.R. (1984). Reflections on perfection. American Psychologist, 39(4), 386390. https://doi.org/10.1037/0003-066X.39.4.386

Parker, W.D. (1997). An empirical typology of perfectionism in academically talented children. American Educational Research Journal. 34(3), 545-562. https://doi.org/10.2307/1163249

Patrzek, J., Sattler, S., van Veen, F., Grunschel, C., \& Fries, S. (2014). Investigating the effect of academic procrastination on the frequency and variety of academic misconduct: A 
panel study. Studies in Higher Education, 40(6), 1014-1029. https://10.1080/03075079.2013.854765

Patton, M. Q. (1980). Qualitative evaluation methods. Thousand Oaks, CA: Sage.

Patton, M. Q. (1999). Enhancing the quality and credibility of qualitative analysis. HSR: Health Services Research, 1189-1208. https://www.ncbi.nlm.nih.gov/pmc/articles/PMC1089059/

Pychyl, T. A., Lee, J. M., Thibodeau, R., \& Blunt, A. (2000). Five days of emotion: an experience sampling study of undergraduate student procrastination. Journal of Social Behaviour and Personality, 15(5), 239 254. https://psycnet.apa.org/record/200210572-019

Rice, K. G., \& Ashby, J. S. (2007). An efficient method for classifying perfectionists. Journal of Counselling Psychology, 54(1), 72-85. https://doi.org/10.1037/0022-0167.54.1.72

Rice, G. K., Ashby, S. J., \& Gilman, R. (2011). Classifying Adolescent Perfectionists. Journal of Psychological Assessment, 23, 563-577. https://doi.org/10.1037/a0022482

Rice, G. K., Leever, A. B., Christopher, J., \& Porter, D. J. (2006). Perfectionism, stress, and social disconnection: A short-term study of hopelessness, depression, and academic adjustment among honours students. Journal of Counselling Psychology, 53, 524-534. https://doi.org/10.1037/0022-0167.53.4.524

Rice, K. G., Richardson, C. M. E., \& Ray, M. E. (2016). Perfectionism in academic settings. In F. M. Sirois \& D. S. Molnar (Eds.). Perfectionism, Health, and Well-being (pp. 245-264), New York, NY: Springer.

Richards, L., \& Morse, J. M. (2013). Read me first for a user's guide to qualitative methods (3rd ed.) Los Angeles, CA: Sage.

Saddler, C.D., \& Sacks, L.A. (1993). Multidimensional perfectionism and academic procrastination: Relationships with depression in university students. Psychological Reports, 73(3), 863-871. https://doi.org/10.2466/pr0.1993.73.3.863

Santrock, J.W. (2019). Adolescence. (17th Ed.). McGraw Hill. ISBN10: 1260058786 ISBN13: 9781260058789

Schilling, J. (2006). On the pragmatics of qualitative assessment: Designing the process for content analysis. European Journal of Psychological Assessment, 22(1), 2837. https://doi.org/10.1027/1015-5759.22.1.28

Schubert Walker, L. J., \& Stewart, D. W. (2000). Overcoming the powerlessness of procrastination. Guidance \& Counseling, 16(1), 39.

Schouwenburg, H. C. (1995). Academic procrastination: theoretical notions, measurement, and research. In J. R. Ferrari, J. L. Johnson, \& W. G. McCown (Eds.), Procrastination and task avoidance: theory, research, and treatment (pp. 71-96). New York: Plenum Press.

Schraw, G., Wadkins, T., \& Olafson, L. (2007). Doing the things, we do: a grounded theory of academic procrastination. Journal of Educational Psychology, 99(1), 1225. https://doi.org/10.1037/0022-0663.99.1.12

Shafran, R., \& Mansell, W. (2001). Perfectionism and psychopathology: A review of research and treatment. Clinical Psychology Review, 21(6), 879906. https://doi.org/10.1016/S0272-7358(00)00072-6

Senécal, C., Koestner, R., \& Vallerand. (1995). Self-regulation and academic procrastination. The Journal of Social Psychology, 135(5), 607-619. https://doi.org/10.1080/00224545.1995.9712234

Senécal, C., Julien, E., \& Guay, F. (2003). Role conflict and academic procrastination: A selfdetermination perspective. European Journal of Social Psychology, 33(1), 135-145. https://doi.org/10.1002/ ejsp.144 
Sironic, A. \& Reeve, R. A. (2015). A combined analysis of the frost multidimensional perfectionism scale (FMPS), child and adolescent perfectionism scale (CAPS), and almost perfect scale-revised (APS-R): different perfectionist profiles in adolescent high school students. Psychological Assessment, 27(4), 1471-1483. https://10.1037/pas0000137

Slaney, R. B., \& Ashby, J. S. (1996). Perfectionists: Study of a criterion group. Journal of Counselling and Development, 74(4), 393-398. https://doi.org/10.1002/j.15566676.1996.tb01885.x

Slaney, R. B., Chadha, N., Mobley, M., \& Kennedy, S. (2000). Perfectionism in Asian Indians: Exploring the meaning of the construct in India. The Counselling Psychologist, 28(1), 10-31. https://doi.org/10.1177/0011000000281002

Slaney, R. B., Rice, K. G., Mobley, M., \& Trippi, J. (2001). The revised Almost Perfect Scale. Measurement and Evaluation in Counselling and Development, 34, 130-145. https://doi.org/10.1080/07481756.2002.12069030

Slaney, R. B., Rice, K. G., \& Ashby, J. S. (2002). A programmatic approach to measuring perfectionism: The Almost Perfect Scales. In G. L. Flett \& P. L. Hewitt (Eds.), Perfectionism: Theory, research, and treatment (pp. 63-88). Washington, DC: American Psychological Association. https://doi.org/10.1037/10458-003

Solomon, L. J., \& Rothblum, E. D. (1984). Academic procrastination: Frequency and cognitive-behavioural correlates. Journal of Counselling Psychology, 31(4), 503509. https://doi.org/10.1037/0022-0167.31.4.503

Soenens, B., Luyckx, K., Vansteenkiste, M., Luyten, P., Duriez, B., \& Goossens, L. (2008). Maladaptive perfectionism as an intervening variable between psychological control and adolescent depressive symptoms: A three-wave longitudinal study. Journal of Family Psychology, 22(3), 465-474. https://doi.org/10.1037/0893-3200.22.3.465

Stoeber, J., \& Otto, K. (2006). Positive Conceptions of Perfectionism: Approaches, Evidence, Challenges. Personality and Social Psychology Review, 10(4), 295319. https://doi.org/10.1207/s15327957pspr1004_2

Stoeber, J., \& Stoeber, F. S. (2009). Domains of perfectionism: Prevalence and relationships with perfectionism, gender, age, and satisfaction with life. Personality and Individual Differences, 46(4), 530-535. https://doi.org/10.1016/j.paid.2008.12.006

Stoeber, J. (2012). Perfectionism and performance. In S. M. Murphy (Ed.), The Oxford handbook of sport and performance psychology (pp. 294-306). New York: Oxford University Press.

Stake, R. E. (2010). Qualitative research: studying how things work. New York: Guilford

Steel, P. (2007). The nature of procrastination: A meta-analytic and theoretical review of quintessential self-regulatory failure. Psychological Bulletin, 133(1), 65-94. https://doi.org/10.1037/0033- 2909.133.1.65

Steel, P., Brothen, T. \& Wambach, C. (2001). Procrastination and personality, performance, and mood. Personality and Individual Differences, 30(1), 95-106. https://doi.org/10.1016/S0191-8869(00)00013-1

Speirs-Neumeister, K. L. (2004). Factors influencing the development of perfectionism in gifted college students. Gifted Child Quarterly, 48, 259-274. https://doi.org/10.1177/001698620404800402

Speirs-Neumeister, K. L., Williams, K. K., \& Cross, T. L. (2009). Gifted high-school students' perspectives on the development of perfectionism. Roeper Review, 31(4), 198-206. https://doi.org/10.1080/02783190903177564

Tice, D. M., \& Baumeister, R. F. (1997). Longitudinal study of procrastination, performance, stress, and health: the costs and benefits of dawdling. Psychological Science, 8(6), 454-458. https://doi.org/10.1111/j.1467-9280.1997.tb00460.x 
Tuckman, B. (1990, April). Measuring procrastination attitudinally and behaviourally. Paper presented at the Annual Meeting of the American Educational Research Association, Boston, MA. Abstract retrieved from https://eric.ed.gov/?id=ED319792

Twenge, J. M., Campbell, W. K., \& Freeman, E. C. (2012). Generational Differences in Young Adults ${ }^{\text {ee }}$ Life Goals, Concern of Others, and Civic Orientation. Journal of Personality and Social Psychology, 102(5), 1045-1062. https://doi.org/10.1037/a0027408

Van Eerde, W. (2003). A meta-analytically derived nomological network of procrastination. Personality and Individual Differences, 35, 1401-1418. https://doi.org/10.1016/s01918869(02)00358-6

Yıldırım, A. \& Şimşek, H. (2011). Qualitative research methods in the social sciences, $8^{\text {th }}$ Ed. Ankara: Seçkin Publ.

Wolters, C. A., \& Corkin, D. M. (2012). Procrastination and Learning. In N. Seel (Ed.), Encyclopedia of the Sciences of learning (pp. 2697-2700). Springer: US. 


\section{Annex 1}

Interview procedure and questions: The interview schedule consisted of two sections. The first section asked demographic questions (age, gender) to provide context for the interview. The next section of the interview consisted of questions about perfectionism and procrastination, to allow the participants to speak of their views in a less structured way. Examples of the interview questions are given in Table 1. Follow-up questions were used to prompt the participants to expand on interesting points or to ask additional questions when appropriate.

Table 1. Examples of Interview Questions

\section{Section Example of Questions}

2 a. What is your motive for trying to be perfect in the academic tasks you frequently do (preparing assignments, completing term projects, preparing for tests) in your education life?

b. What do you need to overcome your situation of trying to be perfect in the academic tasks you frequently do (preparing assignments, completing term projects, preparing for tests) in your education life?

c. What is your motive to procrastinate in the academic tasks you frequently do (preparing assignments, completing term projects, preparing for tests) in your education life?

d. What do you need to overcome procrastination in the academic tasks you frequently do (preparing assignments, completing term projects, preparing for tests) in your education life? 